78 | Muuttuva tekijä 


\section{Salainen ovi}

\section{HarrySalmenniemi}

Ei ole mitään toivoa, ei mitään sanottavaa eikä mitään ymmärrettävää. Ei ole mitään hävettävää.

Suurin osa työstäni on pelkkää kaaosta. En osaa kuvata sitä mitenkään. En tiedä, miksi teen sitä. En tiedä, miten teen sitä. Mikään ei ole käynyt selväksi. Vuosien kuluessa olen uponnut yhä syvemmälle siihen, mitä en ymmärrä, siihen, mistä minulla ei ole mitään käsitystä.

On todennäköistä, että kirjoitan saadakseni selville miksi kirjoitan, ettäjulkaisen kirjoja vain saadakseni tietää miksi julkaisen kirjoja.

Jostakin syystä kirjoitan likaiselle, liatulle paperille. Kirjoitan muiden tekstien päälle.

Alusta asti olen tottunut varastamaan muilta. Ennen kaikkea olen tottunut varastamaan itseltäni. Käyn säännöllisesti läpi varastojani: mitä joku mennyt minä on kirjoittanut, mitä häneltä voi varastaa, mikä kaikki on jo valmista, mistä saisi toimivan tekstin vain muokkaamalla hieman.

Usein on hämärän peitossa, miten joku teksti on syntynyt, kuka on laittanut sen alulle, olenko minä itse kirjoittanut vahingossa tai paniikissa jotakin, vai onko joku aivan muu kirjoittanut jotakin vahingossa ja paniikissa ja minä leikannut sen jostakin talteen.

Kirjoittamiseen ei ole mitään syytä, kirjojen julkaisuun ei ole mitään syytä. Kirjoittaminen on piinaavaa ja kaoottista, julkaiseminen typerää ja häpeällistä.

Kysymys ei ole ollut minkäänlaisesta urasuunnittelusta.

Minulla ei ole uraa eikä suunnitelmaa.

Kun lainaan toisilta, en tee sitä hyötymistarkoituksessa. Teen sen jonkin oudon pakkomielteen tai oikun vuoksi.

Minusta ei ole vastustamaan mieleenjuolahduksiani. Sitä kirjoittaminen pitkälti on: antautumista omille mielijohteille, kontrollista luopumista, periksi antamista.

Julkaiseminen on täydellistä luovuttamista. 
Voin väittää monenlaisia asioita. Voin väittää, että työni on jakautunut kahtia. Voin väittää, että vaivihkaa minulle on kehittynyt kaksi toisiaan täydentävää, toistensa kanssa sotaa käyvää ammattiroolia. Se on melkein totta. Tämä on jo merkittävää: olen löytänyt jonkinlaisen osatotuuden, karkean, yksinkertaistetun mallin.

Minulla on kaksi roolia, ensimmäisen näytän mielelläni muille, toista en mieluiten näkisi edes itse.

Ensimmäinen, näkyvämpi, useammin käytössä oleva rooli on suhteellisen sivistyneen, korkeakoulutetun ihmisen, joka periaatteessa yrittää ottaa vastuuta teoistaan. Hän käyttää laajahkoa tietämystään ja vuosien koettelemia esteettisiä periaatteita erilaisten tekstien viimeistelyyn. Hän voi olla typerä, mutta hän sentään pitää itseään älykkäänä; hän voi olla naurettava, mutta hän sentään onnistuu ottamaan itsensä todesta.

Tämä suhteellisen sivistynyt, melko vastuullinen henkilö ei tahdo loukata ketään, ei halua rikkoa lakia eikä häpäistä tuttaviaan. Hän saattaa olla aivan sekaisin, mutta sentään hän yrittää päivittäin päättää mitä tekee, asettaa tavoitteita: tänään yritän viimeistellä tämän novellin, tämän runokirjan jakson, tämän esseen, muokkaan elokuvan prologin tai epilogin.

Vastuullinen henkilö on ilman muuta merkittävä työntekijä, mutta kuitenkin hän on alisteinen hahmo. Hän ei mahda toiselle, tärkeämmälle hahmolle mitään, koska hän ei itse kirjoita mitään. Hän saattaa ainoastaan viimeistellä, parannella jo olemassaolevaa. Hän editoi ja viimeistelee. Hän on uuttera, kaavamainen ja analyyttisyydessään hieman tylsä.

Toinen, tärkeämpi, yleensä piilossa oleva rooli on kirjoittajan, sotkuisen kaaostehtailijan rooli. Hän aiheuttaa ongelmia. Hän kirjoittaa kaaosta vasten. Hän kirjoittaa epätoivoissaan. Hän ei välitä mistään, koska hänellä ei ole varaa välittää mistään. Hän ei seiso sanojensa takana tai niiden edessä. Hänellä ei ole koulutusta eikä lähimmäisiä. Hänellä ei ole vastuuntuntoa eikä kunnioitusta lakia kohtaan. Hänellä on omituinen, ontto ja häilyväinen käsitys moraalista. Hän kirjoittaa mitä hyvänsä. Hän kuvaa ihmisiä tällä tavoin:

1. Uttersonilla, lakimiehellä, oli karkeat, rumatja epäsäännöllisetkasvot, joita tuskin milloinkaan valaisi hymy; hänen olentonsa oli kylmä ja jäykkä, hän sanoi sanottavansa vain vaivalla, hänen esiintymisessään tuskin voitiin nähdälämpimämpäin tunteiden ilmenemismuotoja; hän 
oli laiha, pitkä, kuiva, synkkä - mutta sittenkin täytyi hänestä pitää. Ystäväpiirin yhtymisissä, kun viini oli hänen makunsa mukaista, loisti hänen silmistään ilme, joka oli jaloimmassa merkityksessä inhimillinen; mutta tämä sisäinen maailma ei kuitenkaan koskaan tullut ilmi sanoissa, vaan sitä useammin ja puhuvammin teoissa. Hän oli ankara itseään kohtaan; joi yksin ollessaan katajanmarjaviinaa, haihduttaakseen hienojen viinien makua, ja vaikka hän nautti teatterista, ei hän ollut avannut sen ovea kahteenkymmeneen vuoteen. Mutta hän oli hyvin suvaitsevainen muiden suhteen; hän tunsi melkein kateudensekaista kummastusta syrjäisten vioissa ja synneissä ilmenevän elinvoiman johdostajajoka tapauksessa mieluummin auttoi kuin valitti.

Kirjoittaja, kaaostehtailija kehtaa mitä hyvänsä. Hän kuvaa ihmisiä sellaisina kuin heidät todella näkee. Hän siteeraa omana tekstinään Robert Louis Stevensonin teosta Salaperäinen ovi, jonka maailma tuntee paremmin nimellä Jekyllja Hyde. ${ }^{1}$

Tämä tärkeämpi ammattirooli ottaa jatkuvasti selittämättömiä, omituisia vapauksia. Hän todellakin luulee kirjoittaneensa kaiken tekstin, myös sen, joka tulee jostakin aivan muualta. Hän saa kimmokkeita mistä hyvänsä, omista unistaan, muiden kertomuksista, repliikeistä,jotka ovat valmiita runonsäkeitä tai kelpaavat novelleihin sellaisenaan, vanhoista, unohtuneista muistiinpanoistaan. Kaikki aineisto on samanarvoista: omat pelot, muiden sattumukset, klassikkoromaanien alut.

En todellakaan tiedä, miksi olen kirjoittanut esimerkiksi Juhani Ahon novellin päälle. ${ }^{2}$ Ei siinä ole mitään järkeä. Mitä enemmän mietin tekoani, sitäjärjettömämmältä ja ilahduttavammalta se vaikuttaa.

Silloin tällöin tapaan ystäviäni työpäivän keskellä. Käymme lounaalla,

1Suomennos on vuodelta 1911, ja sen on julkaissut Otava. Suomentajaa ei ilmoiteta. Löysin tämän tekstikappaleen työpöydältäni punertavan, keraamisen kahvikupin alta.

2 Novellikokoelmani Uraanilamppu ja muita novelleja (2017) niminovelli perustuu Juhani Ahon novelliin "Siihen aikaan, kun isä lampun osti”. Myös monilla muilla novelleillani on lähteitä, joista tehdään selkoa teosten lopussa, ja salaisia lähteitä, joita suurinta osaa en itse muista. Novellikokoelmissani olen noudattanut lähteiden merkitsemisessä seuraavaa periaatetta: Jos novelleihin on selvä yksi päälähde, jota ilman novelli ei olisi voinut syntyä, olen sen ilmoittanut. Pienet ja huomaamattomat lainat, joiden lähteet olen usein itsekin ehtinyt unohtaa, olen jättänyt merkitsemättä. 
kahvittelemme, juttelemme kirjallisuudesta tai mistä hyvänsä: tärkeitä tapoja päästä hetkeksi pois itsensä sisältä.

Yleensä kaikki sujuu hyvin. Järjestelmällinen, järkevä rooli on hallitsevassa asemassa, työn kaaos ei vuoda keskusteluun. En sano mitään täysin käsittämätöntä. Ajatukset ovat jäsentyneitä, sisäisen editorin kurinalaisuus pitää ajatusloikat kestävän mittaisina. Minua voi seurata ja ymmärtää sen verran kuin avoimesti ja tarkasti puhuvaa ihmistä voi.

Joskus harvoin käy toisin. Joku ystävä tulee käymään työhuoneellani, pistäytyy lainaamassa jotakin tai päättää vain spontaanisti käydä tervehtimässä. Tulen yllätetyksi, nähdyksi kaaoksen keskellä. Papereita on siellä täällä, kaikki täyteen kirjoitettua, vanhahtavaa suomea, englannin ja italiankielisiä aineistoja, irtonaisia repliikkejä, aforismeja, huonoja runoja, hieman parempia runoja, novelleja, joista puuttuu takaumia, romaanikäsikirjoituksia, joissa ei ole alkua, keskikohtaa eikä loppua, muttajonkinlainen kiehtova tunnelma sentään.

Tällöin hyvätkin ystävät ovat saattavat säikähtää: tuollainen hullu, niin oman maailmansa sisässä, tuota se siis tekee kaiket päivät, tuohan on ihan älytöntä.

Puheeni on katkeilevaa, itseensä käpertyvää. En osaa ottaa muita huomioon, en tajua, mitä minulle sanotaan. Vaisuna ohjaan ihmiset pois luotani. Yleensä siihen ei ole tarvetta: he lähtevät itse, kuin aaveen nähneenä.

Nyt vasta saatoin nähdä hänet oikein. Niin paljon oli ainakin varmaa, etten ollut nähnyt häntä koskaan ennen. Hän oli, kuten sanoin, pienikokoinen; minua hämmästytti vielä hänen tavattoman epämiellyttävä ja tympäisevä katsantonsa, hänen ponneton ja lihakseton ruumiinrakenteensa sekä - eikä vähimmin - se outo vaikutus, jonka hänen läsnäolonsa teki minuun. Se vivahti alkavaan kangistumiseen, jota seurasi valtimon huomattava heikentyminen. Silloin en kiinnittänyt siihen kovinkaan paljon huomiota, arvelin sen johtuvan vain sairaalloisesta persoonallisesta vastenmielisyydestä, vaikkakin oireen terävyys ihmetytti minua; mutta sittemmin on minulla ollut syytä olettaa, että syy oli paljoa syvemmälläja että sillä oli jalompi juuri kuin vain pelkkä viha. ${ }^{3}$

3 Katkelma on niin ikään samaisesta Stevensonin kirjasta. Tämä sivu oli kulkeutunut työhuoneeni kirjahyllyyn. Löysin sen muistikirjani ja Anne Carsonin Sapfo-käännöksen välistä. 
Jo vuosia työhuoneellani on vaeltanut Salaperäinen ovi. Olen tulostanut sen Project Gutenbergista. Printeissä ei ole sivunumeroita. Vuosien aikana paperipino on mennyt pahasti sekaisin.

Olen ajatellut, että siitä voisi saada hauskoja pätkiäjohonkin romaaniin. Etenkin lopun kirje on koskettava. Muokattuna se voisi toimia monenlaisen romaanin loppuna. Siitä saattaisi saada häiritsevän tai hauskan lopun avioliittodraamaan, epäuskottavan yrityksen uskottomuuden selitykseksi. Työni on myös tällaista: sopimattomien lähteiden käyttöä väärissä paikoissa, kekseliästä mielettömyyttä.

Kaksi hahmoa, jotka ovat ristiriidassa ja juuri siksi täydentävät toisiaan - sellaisesta saisi tietenkin hyvän lopun tällaiselle tekstille. Kaksi ammattiroolia, kliseinen kaksoishenkilöteema, vaivaannuttavan keittiöpsykologinen ymmärrys siitä, miten ihminen ei ole koskaan yhtenäinen.

Kuitenkaan mikään ei ole näin yksinkertaista.

Ei ole mitään kahta, on valtava määrä erilaisia rooleja, erilaisia voimia, minuuksia.

Ei ole kahta ammattiroolia, jotka voisi todella erottaa toisistaan, ei edes kirjoittajaa ja lukijaa erillä toisistaan.

Vaikutus, jonka tekstini tekevät lukijaan, on minulle mysteeri. En osaa ennakoida tai selittää sitä. Vaikutukset perustuvat teksteihin, joita lukijat ovat lukeneet aikaisemmin. He sekoittavat kaiken päässään. He liittävät lauseeni oman elämänsätapahtumiin. He samastuvat. Se on kammottavaa.

Lukijat ovat vastenmielisiä, he ovat aivan yhtä sekavia kuin kirjoittajat. En voi kontrolloida mitään.

Muiden kirjoittamat tekstit antavat usein merkityksen omalle tekstille. Sille ei mahda mitään: meidät on kiinnitetty toisiimme niin naurettavan monilla langoilla.

Merkitykset ja sisällöt tulevat muualta.

Myös muodot tulevat muualta.

Kirjoittaminen on kontrollin kadottamista.

Jos on olemassa kaksi tärkeää päähenkilöä, ne ovat muoto ja sisältö,jotka tietenkin kietoutuvat aina toisiinsa.

Muodot ovat tärkeämpiä kuin sisällöt. 
Runoissa muoto on usein lähes kaikki: runojen tekeminen on muotojen ymmärtämistä, niiden lukemista, tutkimista. Novelleissa muoto on lähes kaikki, ja usein se, mitä tajuaajättää sanomatta, on tärkeämpää kuin se vähä, minkä saa sanottua. Romaaneissa muoto on lähes kaikki, tapa rakentaa maailma, henkilöt, mahdollinen juoni, tapa rytmittää aineistoa, käyttää aineistoa, käyttää anekdootteja, annostella aforismeja.

Jos kirjailija varastaa toiselta muodon, hän varastaa toiselta lähes kaiken. Ja kirjailijat todella varastavat toisiltaan kaikkea: muotoja, lauseita, sanoja, hiljaisuuksia, tavan rytmittää dialogia, tavan kuvata luontoa, tavan käyttää murteita, tavan käyttää kuvia, tavan viitata muiden teoksiin, tavan viitata omiin teoksiinsa.

Toisinaan kirjailijatvarastavat tahallaan, mutta useimmiten he tekevät niin vahingossa.

Jostakin muualta tekstiin virtaa merkityksiä, sotkua, kaaosta, tunnelmaa, repliikkejä, tunteita.

Salainen ovi on aina auki. 